\title{
Overview of the aeroponic agriculture - An emerging technology for global food security
}

\author{
Imran Ali Lakhiar, Jianmin Gao*, Tabinda Naz Syed, Farman Ali Chandio, \\ Mazhar Hussain Tunio, Fiaz Ahmad, Kashif Ali Solangi \\ (School of Agricultural Equipment Engineering, Jiangsu University, Zhenjiang 212013, Jiangsu, China)
}

\begin{abstract}
Traditionally, crops are cultivated in soil-based open field systems. Seasonality, environmental degradation, urbanization, and food security issues have replaced open-field systems with modern plant production systems. Soilless culture is one of the modern plant production systems, which involves much higher use of available resources. The presented study provides information about currently accessible soilless systems and discussed the aeroponic system. Compared to other soilless systems, aeroponic reduce water usage through continuous water circulation. However, the aeroponic is not entirely implemented among local farmers, and very few farmers have adopted the system due to the lack of research and technical information available in the literature. Therefore, this study was planned to provide information about the development and maintenance tasks required for practicing the aeroponic system. This study could provide knowledge to the researchers, farmers, and those people interested in practicing the aeroponic system.
\end{abstract}

Keywords: aeroponic, food security, hydroponic, soilless culture, substrate culture

DOI: $10.25165 /$ j.ijabe.20201301.5156

Citation: Lakhiar I A, Gao J M, Syed T N, Chandio F A, Tunio M H, Ahmad F, et al. Overview of the aeroponic agriculture - An emerging technology for global food security. Int J Agric \& Biol Eng, 2020; 13(1): 1-10.

\section{Introduction}

In the future, the world population will deal with several difficulties, problems, and issues that can have adverse impacts on the overall future food production (FFP) and food security ${ }^{[1-3]}$. Studies reported that the challenges, problems, and issues are forecasted due to the continuous effects of unexpected climate changes, increasing geographic extent of drylands, population growth, increasing urbanization, rising costs of agribusiness, soil depletion and degradation, water shortages, water pollution, overexploitation of groundwater, and reduced production practices $^{[4-7]}$. A study by Lam et al. ${ }^{[8]}$ informed that the rapid increase in urbanization, industrialization, and modernization could have profound effects on FFP and food safety issues. Besides, peoples' living style is rapidly changing from a lower standard to a higher standard, and they have started to move from small towns to big cities. This rapid rise in urbanization and infrastructures can create several problems for the agriculture sector because peoples have started to convert their arable lands into commercial and residential areas. Xiao et al. ${ }^{[9]}$ concluded that if we take China as an example, the rise of urbanization and infrastructure development in China is increased very fast compared to other countries of the world. However, the share of the urban population is increased

\section{Received date: 2019-05-20 Accepted date: 2019-12-05}

Biographies: Imran Ali Lakhiar, PhD candidate, research interests: fog tilling, Email: 5103160321@stmail.ujs.edu.cn; Tabinda Naz Syed, PhD candidate, research interests: aeropoics, Email: 5102160315@stmail.ujs.edu.cn; Farman Ali Chandio, Associate Professor, research interests: agricultural machinery, Email: farman@ujs.edu.cn; Mazhar Hussain Tunio, PhD candidate, Lecturer, research interests: irrigation engineering, Email: mazharhussaintunio@ sau.edu.pk; Fiaz Ahmad, Post-doctorate, research interests: agricultural michinery, Email:fiazahmad@bzu.edu.pk; Kashif Ali Solangi, PhD candidate, research interests: soil salinity control, Email: 5103180312@stmail.ujs.edu.cn. *Corresponding author: Jianmin Gao, Professor, research interests: soil and fog tilling, No.301 Xuefu Road, Zhenjiang city, Jiangsu Province, China. Tel: +86-13655282069, Email: gaojianminujs@163.com. from $21.1 \%$ to $58.5 \%$ over the period $1982-2017^{[10-13]}$. Lakhiar et al. ${ }^{[2]}$ reported that the global climate change urbanization, industrialization, and modernization becomes a critical influencing factor for FFP and the impact cannot be ignored ${ }^{[14,15]}$. Shamshiri et al. ${ }^{[16,17]}$ stated that FFP could exemplify by adopting modern farming techniques such as the implementation of the greenhouse plant cultivation (GPC) and agricultural robotics technologies (ART) in traditional agriculture. These modern techniques involve much higher use of advanced technology and automation for land-use optimization. By adopting these techniques, modern farms can expect to produce more yields with higher quality at lower expenses in a sustainable way ${ }^{[18]}$. Moreover, the greenhouse defined as a covered structure that provides plants with optimally controlled microclimate growth conditions. It reduces production costs and increases crop yields ${ }^{[19,20]}$. Another study of Shamshiri and Ismail ${ }^{[21]}$ informed that over the last decades, the increasing population had changed the food production scenario. This study further reported in 91 developing countries, the most of the available land area is not in use for crop production, which is 2.4 times higher than the area in use for performing the agriculture activities $^{[22]}$. Since the available land could not increase, so the GPC has been employed as a solution to make more effective use of available space in hands. A study by Chang et al. ${ }^{[23]}$ revealed that GPC is one of the world's most significant agricultural productions system due to its high economic benefits. At present, it had been in rapid development in both developed and developing countries of the world for the cultivation of fruits and vegetable plants ${ }^{[24-27]}$. Moreover, the adoption of GPC could provide a flexible solution for high quality and sustainable year-round plant production, particularly in regions with adverse climate conditions or limited land and resources with increased productivity. It is among the most intensive agricultural systems, requiring high inputs from growers generally greater than growing in the open field. In GPC, air temperature, relative humidity, light level, and $\mathrm{CO}_{2}$ concentration are considered necessary parameters to achieve 
high yield at low expense and to keep the greenhouse environment competitive ${ }^{[28,29]}$. However, several researchers have presented new innovative studies, tools, approaches, and techniques in GPC that have been successful in addressing some of these concerns ${ }^{[30-37]}$. In addition, soilless culture is a promising and innovative technique widely applied in GPC due to its multiple advantages $^{[38,39]}$. Soilless culture is the realization of all types of agricultural production in solid or liquid culture. In many countries of the world, the technique is being significantly used to cultivate several types of fruits and vegetable crops, and about a total of $31000 \mathrm{hm}^{2}$ of soilless systems are reported in the literature ${ }^{[40]}$. Aeroponic cultivation is one of the types of soilless culture, which is significantly practiced in different countries of the world $^{[2]}$. Currently, the aeroponic system is not entirely implemented among local farmers, and very few farmers have adopted the technique due to the lack of research and technical information available in the literature. However, much information about the system is still scientifically unclear, and several aspects of the system have yet to be investigated and improved to get significantly higher plant production ${ }^{[41,42]}$.

Therefore, this study was planned to provide information about the development and maintenance tasks required for practicing the aeroponic system. However, the rest of the paper is organized as follows: Section 2 describes the soilless culture and its types. Sections 3 and 4 represent the status of the existing aeroponic products and systems, development of the aeroponic systems, main parts of the aeroponic system and additional required material and manufacturing of the different aeroponic systems. Sections 5, 6, 7, and 8,9 describe the evaluation of proposed aeroponic system, technical challenges, routine and preventative maintenance of the aeroponic system, advantages of the aeroponic system, future prospectus. Finally, Section 10 represents the conclusion of the study.

\section{Soilless culture}

Soilless culture is the technique of plant cultivation without the use of soil by providing water and solid particle as a rooting medium $^{[43]}$. It is primarily associated with the method of substrate culture and water culture (Figure 1). The soilless culture can be practiced in two conditions: 1) open environment agriculture, and 2) controlled environment agriculture. Studies suggested that compared to soil-based cultivation, soilless production is more cost-effective, higher yields, and quicker harvests from smaller areas of land ${ }^{[44-46]}$.

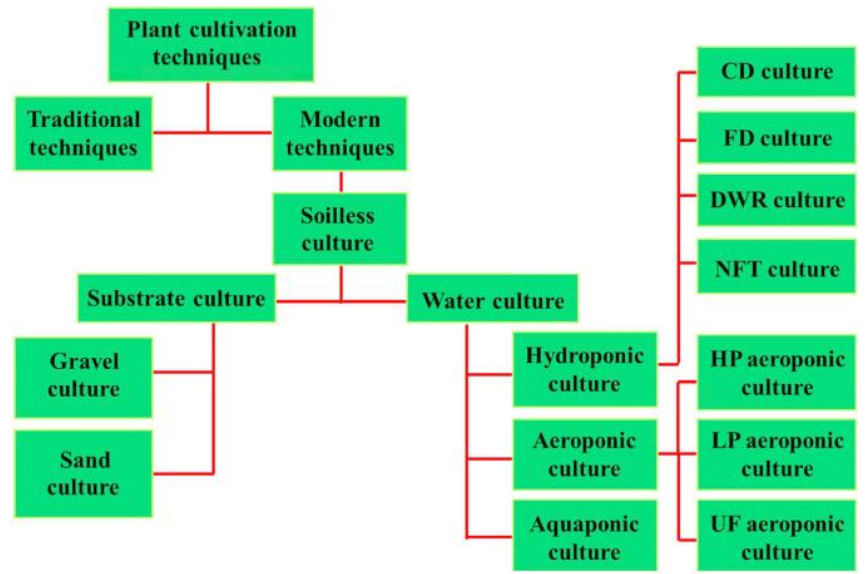

Note: CD: Continuous drip; FD: Flood and drain; DWR: Deep water raft culture; NFT: Nutrient film technique; HP: High-pressure; LP: low-pressure; UF: Ultrasonic fogger.

Figure 1 Flow chart of plant cultivation techniques
Furthermore, it facilitates many socio-economic benefits, including it can deal with the increasing global food challenges, environmental changes for the mitigating, management, malnutrition, and efficient utilization of the available natural resources $^{[47]}$. The technique can provide sustained, sufficient, fresh, clean, and hygienic vegetable supply throughout the year without any interval by using minimum inputs and facilitates multiple plant harvesting with maximum output ${ }^{[1]}$. The concept of the soilless culture seeks to offer an innovative solution to ensure the environmental and economic sustainability of food supplies with high nutritional quality. It is a highly recommended plant cultivation technique for all countries having less arable land, rapid environmental changes, and increasing food challenges with the indigenous population ${ }^{[48]}$.

\subsection{Substrate culture}

The substrate culture defined as the cultivation of crops in a solid, inner, or non-inert medium instead of soil or water culture. At present, several researchers are using different types of substrate cultures for their research studies ${ }^{[49]}$. Moreover, the substrate material can be constructed from both inorganic and organic components. The organic substrates include sawdust, coco peat, peat moss, woodchips, fleece, marc, bark and inorganic substrate includes perlite, vermiculite, zeolite, gravel, rockwool, sand, glass wool, pumice, sepiolite, expanded clay, volcanic tuff, and synthetically produced substrates such as hydrogel, foam mates (polyurethane), and an oasis (plastic foam) ${ }^{[51-53]}$. However, the most commonly used material varies, both locally and globally. Research studies reported that peat, coir, wood, and composted materials are the most dominant substrate materials in soilless cultivation, which are commonly used around the world ${ }^{[54-57]}$.

Barrett ${ }^{[49]}$ reported that before selecting the substrate material, it must be ensured that the selected substrate material would perform well in two key areas: 1) The selected material must possess the physical, chemical, and biological properties. Because these properties are necessary to provide suitable growth conditions for plant roots in the challenging environment, 2) The selected material must meet the functional requirements of the production system in which it is being utilized. An effective substrate material must have a physical structure that creates an appropriate balance of air and water for healthy root development. This balance must be maintained over an entire crop production cycle, which can last from several weeks to more than a year ${ }^{[58]}$.

\subsection{Water culture}

Water culture is another type of soilless system. In water culture, the plant grows in a water-rich nutrient solution instead of the substrate material. The roots of the plants are hanged/submerged in the nutrient solution. While the upper portion, such as shoots and fruits are placed above the supporting trays. The water culture is further categorized into three main types such as hydroponics, aquaponics and aeroponic cultivation systems $^{[1,59]}$.

\subsubsection{Hydroponic cultivation}

Hydroponic is a method of growing crops without the use of soil, where the roots of the plants are submerged in the nutrient solution ${ }^{[60]}$. Recently, the use of the technique in agriculture is significantly increased, as it provides several advantages over traditional soil-based cultivation ${ }^{[61]}$. One of the primary advantages of this method is to allow the more efficient use of available resources and provides an opportunity to better control climate and pest factors ${ }^{[62-64]}$. Hydroponic production increases crop quality and productivity, which results in higher 
competitiveness and economic incomes. Furthermore, it requires low-maintenance as well, insofar as weeding, tilling, kneeling, and dirt removal are non-issues and provides a less labor-intensive way to manage more extensive areas of production ${ }^{[65,66]}$. Studies reported that there are many types of hydroponic systems, but the most common types are NFT, DWR (Figure 2), and FD. Also, it can be classified by the container type (window boxes, troughs, rails, buckets, bags, slabs, and beds) ${ }^{[67-69]}$

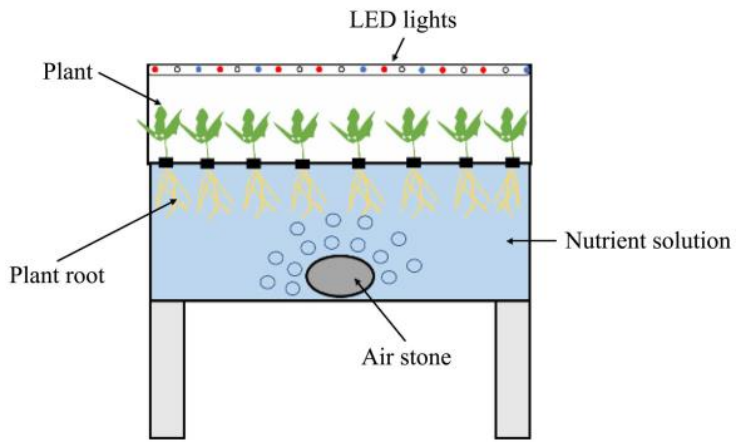

Figure 2 Hydroponic system

\subsubsection{Aquaponic cultivation}

The aquaponic system is an advanced food production technique of modern farming that combines the production of aquatic organisms with plant production. It is an innovative method that potentially contributes to both populations' demand for animal products and sustainable consumption patterns ${ }^{[70]}$. It offers more than $50 \%$ of the nutrients for optimal plant growth through recycling of the nutrient-rich wastewater from feeding the aquatic organisms into the system. Thus, it reduces the use of fertilizers of mineral origin and the environmental impact of both fish and plant production ${ }^{[71-76]}$. Besides, the aquaculture wastewater to fertilize the plants can avoid the discharge of phosphorus- and nitrogen-enriched water into the already nitrogen-loaded surface- and groundwater ${ }^{[77]}$. Schröter and Mergenthaler ${ }^{[78]}$ reported that several research studies suggested that expansion of the aquaponic sector will probably provide a solution to the declining global capture fisheries and the future food production. Figure 3 shows the aquaponic system.

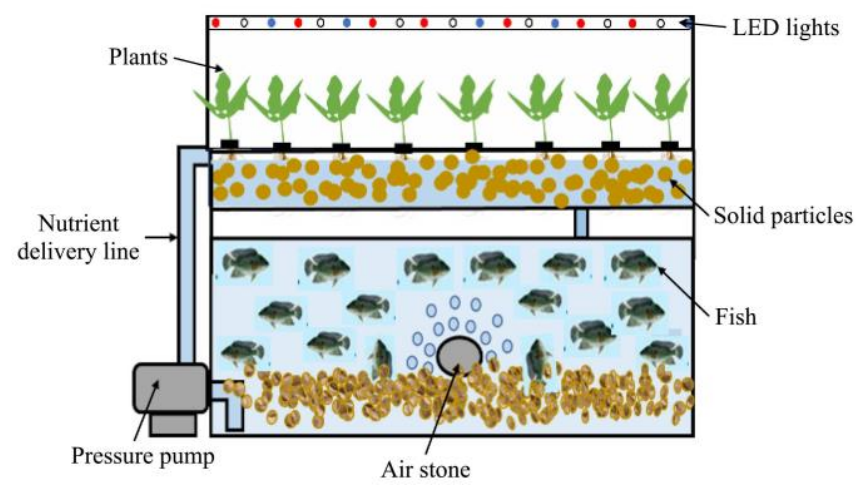

Figure 3 Aquaponics system

\subsubsection{Vertical farming}

Vertical farming is the practice of growing fruits, vegetables, and non-edible plants in vertically-stacked layers or multi-story buildings containing an environment conducive. These "farms" make use of enclosed structures like warehouses and shipping containers to provide a controlled environment for growing the crops in the hydroponic system, aeroponic system, and aquaponics system. Shamshiri et al. ${ }^{[16]}$ reported that the concept of vertical farming was not new, and the studies suggested that the technique was unknown for a long time. In recent years, with the rapid advancement in technology and increasing land issues, researchers moved towards vertical farming as an alternative food production system. Vertical farming offers several benefits, including independence from arable land, year-round growing capacities, less water consumption, and improved crop predictability. It can also promote sustainable agricultural practices compared to conventional farming ${ }^{\text {[79-81] }}$.

\subsubsection{Aeroponic cultivation}

The aeroponic system is one of the techniques of the soilless culture, where the plant grows in the air with the assistance of artificial support instead of soil or substrate culture. The term aeroponic was taken from the Greek, and Latina terms Aero and Ponic, which means air and labor. It is an air-water plant growing technique in which plant lower portions such as roots are hanged inside the growth chamber under complete darkness. Whereas the upper portions of the plant, such as leaves, fruits, and the crown portions are extending outside the growth chamber ${ }^{[82-85]}$. The technique is economical in the use of fertilizers and saves water nutrient solution compared to other soilless systems ${ }^{[86-92]}$. Several studies had been practiced the technique for the cultivation of horticultural ornamental, the root of herbs and root based medicinal plants. These studies reported that in an aeroponic system, plant roots quickly nourish under the available nutrients and controlled conditions. The controlled conditions include uniform nutrients concentration, EC (Electrical conductivity) and $\mathrm{pH}$, temperature, relative humidity, light intensity, spraying time, spraying interval, and $100 \%$ oxygen availability in the growth chamber ${ }^{[93-100]}$. Furthermore, the detailed information about the aeroponic system is published in the previous studies of Lakhiar et al. ${ }^{[1,2]}$

\section{Status of the existing aeroponic products and systems}

At present, the aeroponic system is practiced for commercial, experimental, and kitchen gardening. O'Hare airport in Chicago is one of the most recent examples; it has recently introduced a highly innovative sustainable food and beverage supply chain on-site aeroponic system ${ }^{[101]}$. People are growing plants in the aeroponic system on their balconies, terrace, and rooms due to its competed structure ${ }^{[102]}$. In addition, throughout the literature review, it was found that several online websites were engaged with the aeroponic business at local and international levels, and they were offering several types, sizes, and shapes of the aeroponic systems. We found that the available structures were expensive, and they were providing services for limited countries of the world. Guizhen $^{[103]}, \mathrm{Gao}^{[104]}$, and NASA ${ }^{[105]}$ reported that the aeroponic system has mainly four types of structures, including seedbed type, vertical barrel type, prototype, and pyramid type. These types are commonly practiced around the globe for growing the various types of fruits, vegetables, and medicinal based plants. These structures are the basic structures of the aeroponic system and simple to build by using wood, aluminum, and plastic material.

\section{Development of the aeroponic systems}

Throughout this review, it was found that no scientifically recommended and convenient aeroponic system developed for plant growth. Several researchers, scientists, and local farmers developed aeroponic systems according to their requirements and available space. A study by Juncal et al. ${ }^{[106]}$ informed that aeroponic had been in use for decades, besides up to now, no adequate structural arrangements are created and recommended for designing the aeroponic system. In addition, the aeroponic 
systems are mainly comprised of the three main portions, including 1) growth chamber, 2) plant supporting portion, and 3) nutrient supply system. For the present study, we selected two types of aeroponic structures (seedbed type and pyramid type), and a total of eight different aeroponic systems were developed. Among them, seven systems were the seedbed type, and one system was the pyramid type. Aeroponic systems were developed by using two types of atomization nozzles (mechanical atomizer and ultrasonic foggers). The mechanical nozzles were included three air-assisted atomizers and one centrifugal atomizer. The ultrasonic nozzles were included three atomization ultrasonic frequencies high-frequency medium-frequency and low-frequency. Furthermore, the aeroponic systems were built with mechanical atomizers and one low-frequency ultrasonic atomizer developed in three main portions, including a growth chamber, nutrient reservoir, and stand to fix the growth box. The aeroponic system with high-frequency and medium-frequency ultrasonic aeroponic atomizers was developed in two main portions, including the growth chamber and a stand to fix the growth chamber. Additionally, the aeroponic system developed with wood is considered as more durable and cheaper, but the system developed with wooden frames is easily susceptible to rapid water damages. Therefore, aluminum frame and plastic material were used to develop different aeroponic systems.

\subsection{Main parts and required material of the aeroponic system}

In an aeroponic system, the growth chamber and a nutrient reservoir are the same types of containers that are used to hold the plant roots, aeroponic atomization nozzles, and store the nutrient solution. Therefore, the growth chamber and nutrient reservoir can be considered as one of the important parts of the aeroponic system. Moreover, the growth chamber is designed to openly hold the plant roots in the air under complete darkness and to provide suitable growth conditions for the plants such as humidity, temperature, dissolved oxygen, and nutrient spray. Also, the aeroponic atomization nozzles are assembled in the growth chamber where atomizers atomize the direct nutrient spray on the

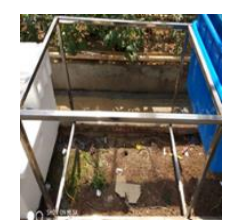

A1

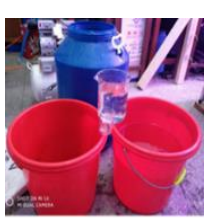

A9

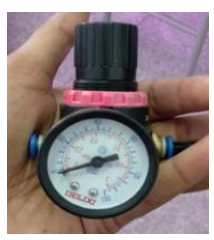

A17

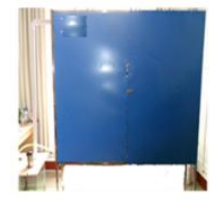

A2

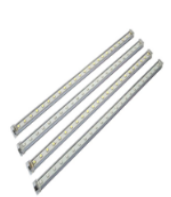

A10

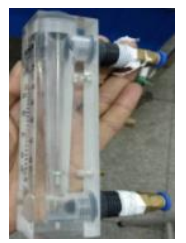

A18

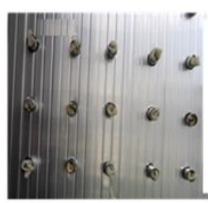

A3

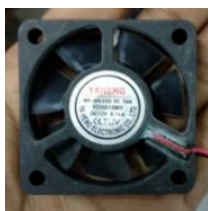

A11

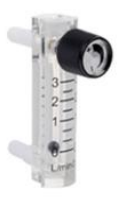

A19

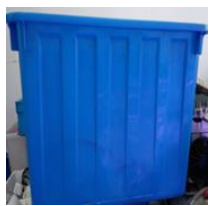

A4

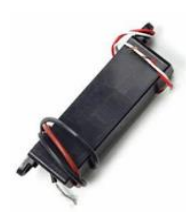

A12

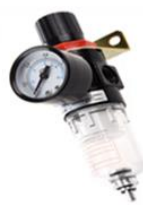

A20 plant roots. The growth chamber and nutrient solution reservoir can be made from wood, plastic, and aluminum materials. However, wooden frames must be lined with plastic sheeting for avoiding the water leakages from both reservoirs. Another important consideration is the color of the reservoirs, the dark color is recommended, but any significantly opaque plastic can be used to develop both reservoirs. It should be avoided to use the translucent plastic as it allows light to enter the reservoirs, and encourage the growth of algae. Also, it should be ensured to protect both reservoirs to prevent light penetration and to reduce the amount of dirt and debris. In an aeroponic system, plant roots receive direct nutrient mist supply ejecting from the different types of the atomization nozzles (air-assisted, centrifugal and ultrasonic high-, medium- and low-frequency ${ }^{[108-110]}$. Until now, several research studies developed the different types and sizes of the aeroponic systems. However, no single study had intensely focused and briefly discussed the selection of the suitable aeroponic atomization nozzles ${ }^{[111-116]}$. Moreover, this study was first to develop the aeroponic system using electrostatic spray technology in the aeroponic system. Samuel et al. ${ }^{[117]}$ reported that electrostatic spray technology is the process of spraying an electrostatically charged mist into the surfaces and selected objects. The electrostatic spray uses a specialized solution combined with air and atomized by an electrode inside the sprayer. The air-assisted electrostatic sprayers can produce the droplets smaller than those produced by conventional or hydraulic sprayers ${ }^{[118,119]}$.

In addition, the selected atomizers were such as Hartmann air-assisted atomization nozzle with resonance tube; air-assisted atomization nozzle with and without electrostatic spray; centrifugal atomization nozzle; $1.7 \mathrm{MHz}$ high-frequency ultrasonic fogger atomization nozzle with three ultrasonic transducers, $1.7 \mathrm{MHz}$ high-frequency ultrasonic fogger atomization nozzle with one ultrasonic transducers, $107 \mathrm{kHz}$ medium-frequency ultrasonic fogger atomization nozzle, and $28 \mathrm{kHz}$ low-frequency ultrasonic fogger atomization nozzle. The additional required material is shown in Figure 4.

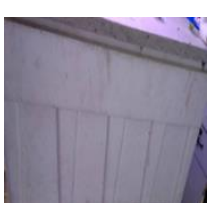

A5

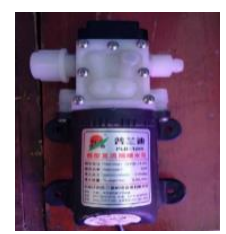

A13

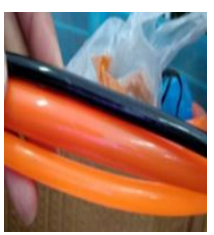

A21

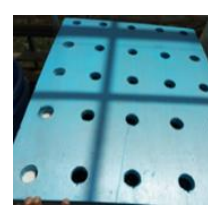

A6

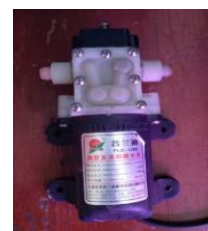

A14

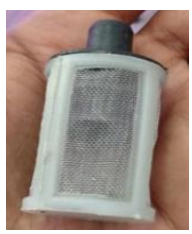

A22

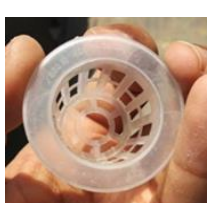

A7

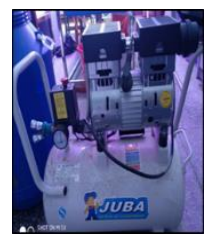

A15

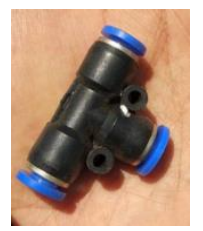

A23

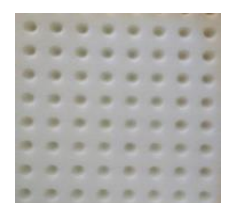

A8

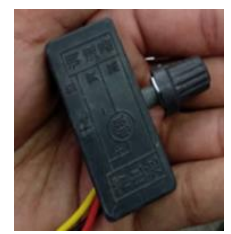

A16

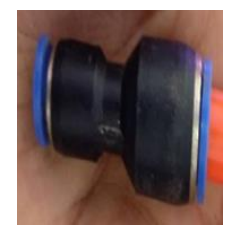

A24

Figure 4 Components and material required for developing the aeroponic system

Moreover, the additional required material for developing the aeroponic systems were $\mathrm{A} 1=$ aluminum frame $745 \mathrm{~mm} \times 550 \mathrm{~m} \times$ $800 \mathrm{~mm}$ and $745 \mathrm{~mm} \times 450 \mathrm{~mm} \times 800 \mathrm{~mm}, \mathrm{~A} 2=$ stainless steel growth box $800 \mathrm{~mm} \times 300 \mathrm{~mm} \times 800 \mathrm{~mm}$ with total height
$1100 \mathrm{~mm}, \mathrm{~A} 3=$ plant supporting tray $800 \mathrm{~mm} \times 300 \mathrm{~mm} \times 800 \mathrm{~mm}$, A4 = plastic box $740 \mathrm{~mm} \times 540 \mathrm{~mm} \times 400 \mathrm{~mm}$, A5 = polystyrene foam box $740 \mathrm{~mm} \times 440 \mathrm{~mm} \times 300 \mathrm{~mm}, \mathrm{~A} 6=$ Styrofoam $760 \mathrm{~mm}$ $\times 560 \mathrm{~mm} \times 10 \mathrm{~mm}$ and $745 \mathrm{~mm} \times 445 \mathrm{~mm} \times 10 \mathrm{~mm}, \mathrm{~A} 7=$ plastic 
cup to hold the plant $45 \mathrm{~mm} \times 30 \mathrm{~mm} \times 45 \mathrm{~mm}, \mathrm{~A} 8=$ cotton round hole $25 \mathrm{~mm} \times 25 \mathrm{~mm} \times 25 \mathrm{~mm}$, A9 $=$ plastic tank for nutrient solution $50 \mathrm{~L}$ and $25 \mathrm{~L}, \mathrm{~A} 10=$ LED lights (Model: WT-ZWD-3R2B1W-600MM-9W, $900 \mathrm{~lm}, \quad$ Xiamen Plants Agricultural Photoelectricity Technology Co., Ltd. P.R China), $\mathrm{A} 11=12 \mathrm{~V}$ axial fan, $\mathrm{A} 12=12 \mathrm{~V}$ high voltage electrostatic generator, A13 and A14 = demographic pumps, model name (Model PLD1204 and 1206, $12 \mathrm{~V}, 0.45 \mathrm{MPa}$ and $1 \mathrm{MPa}$, Shijiazhuang City Prandy Electromechanical Equipment Co., Ltd.), A15 = air compressor (Model 750-30<2530>, Zhejiang Shengyuan Air Compressor Manufacturing Co., Ltd.), A16 = demographic pump pressure regulator, A17 = demographic pump pressure meter, A18 = water flow meter, A19 $=$ air flow meter, A20 $=$ air pressure meter, A21 = flexible polyethylene water supply line $6 \mathrm{~mm} \times 8 \mathrm{~mm}$, $8 \mathrm{~mm} \times 10 \mathrm{~mm}$ and $12 \mathrm{~mm} \times 14 \mathrm{~mm}, \mathrm{~A} 22=$ plastic filter with stainless steel net, A23 = pneumatic three-way connector $6 \mathrm{~mm} \times$ $6 \mathrm{~mm} \times 6 \mathrm{~mm}, \mathrm{~A} 24=$ pneumatic reducer air pipe joint $8 \mathrm{~mm} \times$ $12 \mathrm{~mm}$.

\subsection{Manufacturing of the different aeroponic systems}

The aeroponic systems developed with Hartmann air-assisted atomization nozzle with resonance tube, air-assisted atomization nozzle with and without electrostatic spray were mainly composed of a growth chamber, a plant supporting tray, an atomization nozzle, a nutrient delivery line, a nutrient drain line, and a nutrient reservoir. Firstly, the dimensions of the aeroponic systems were finalized, which were based on the experiment requirement and available space. The system can be any size and shape. However, the further procedure is given in the below sections.

4.2.1 Aeroponic system developed with air-assisted atomizers

The aeroponic systems with air-assisted atomizers were developed by using one atomization nozzle. The selected nozzle was placed into the center of the growth chambers. However, the selected dimensions of the aeroponic growth chambers, stand frames, and the nutrient reservoirs were $740 \mathrm{~mm} \times 540 \mathrm{~mm} \times$ $400 \mathrm{~mm}$ (A4), $745 \mathrm{~mm} \times 550 \mathrm{~mm} \times 800 \mathrm{~mm}$ (A1), 50 L capacity (A9), respectively. In addition, firstly, the drill machine was used to make the holes for the atomization nozzle, and the water recycles line in the growth chamber (A4). After that, the one atomization nozzle and one pneumatic male thread joint connector were located in the center of the growth box (A4). Further, the two pneumatic male thread joint connectors $(8 \mathrm{~mm} \times 10 \mathrm{~mm})$ were assembled within the atomization nozzle water inlet valve and the air inlet valve. In order to avoid the water and air leakages from the air and water inlet valves, the thread joint connectors were wrapped with a couple of layers of Teflon tape before assembly. The nozzle water inlet and air inlet valves connected with the pneumatic copper male thread joint connectors $(8 \mathrm{~mm} \times 10 \mathrm{~mm})$ were further linked with the flexible polyethylene line (A21 $(8 \mathrm{~mm} \times 10 \mathrm{~mm})$ ) to receive the water and air supply. The water supply line was further linked with the nutrient storage tank (A9) through the water supply system. However, the water supply system consisted of the pressure pump (A13), fluid pressure measuring pump (A17), and liquid flow meter (A17). Briefly, the pressure pump suction side and water delivery portion were connected with a flexible polyethylene water line $(\mathrm{A} 21(12 \mathrm{~mm} \times 14 \mathrm{~mm}))$. The suction line was further connected with the filter (A22) and dipped in the nutrient reservoir (A9), whereas the water delivery portion of the pressure pump (A13) was connected with the pneumatic reducer air pipe joint (A24). Further, the pneumatic joint (A24) was connected with a flexible polyethylene water supply line (A21 $(8 \mathrm{~mm} \times 10 \mathrm{~mm}))$. In next step, the flexible polyethylene line
(A21 $(8 \mathrm{~mm} \times 10 \mathrm{~mm})$ ) coming from the pressure pump was connected with the fluid pressure measuring pump (A17), and liquid flow meter (A18) through the pneumatic copper male thread joint connector $(8 \mathrm{~mm} \times 10 \mathrm{~mm})$. Furthermore, the flexible polyethylene line $(\mathrm{A} 21(8 \mathrm{~mm} \times 10 \mathrm{~mm}))$ coming from the fluid pressure measuring pump (A17) was attached with the nozzle through the pneumatic copper internal thread straight connector $(8 \mathrm{~mm} \times 10 \mathrm{~mm})$. Moreover, the air supply system consisted of the air compressor (A15), air pressure meter (A20), and airflow meter (A19). The air compressor connected with the flexible polyethylene line $(\mathrm{A} 21(8 \mathrm{~mm} \times 10 \mathrm{~mm}))$ was further connected with the air pressure meter (A20) and airflow meter (A19) through the pneumatic copper male thread joint connectors $(8 \mathrm{~mm} \times$ $10 \mathrm{~mm}$ ). After that, the air supply line coming from airflow meter (A19) was further connected with the flexible polyethylene line $($ A21 $(8 \mathrm{~mm} \times 10 \mathrm{~mm}))$ and finally attached with the nozzle air inlet valve through pneumatic copper male thread joint connector $(8 \mathrm{~mm} \times 10 \mathrm{~mm})$. Besides, for nutrient solution recycling from the growth chamber (A4), the flexible polyethylene line (A21 $(8 \mathrm{~mm} \times 10 \mathrm{~mm}))$ was coupled in the pneumatic male thread joint connector and fixed in the center of the aeroponic growth chamber. After that, the nutrient solution recycling line was placed in the nutrient reservoir (A9). In the next step, the PVC pipe $(25 \mathrm{~mm})$ was fastened with the aluminum frame (A1) to provide support to the LED lights (A10). Therefore, the PVC elbow and tee $(25 \mathrm{~mm})$ were used to make the frame of the PVC pipes $(25 \mathrm{~mm})$. Moreover, the PVC pipes were tightly fastened with a plastic strip. Three LED lights (A10) were placed on the developed PVC frame. The LED lights were further tightly fastened with PVC pipes with the plastic strips. The final step was to prepare the artificial plant supporting layer for holding the plants in the aeroponic growth chamber. Therefore, Styrofoam (A6 $(760 \mathrm{~mm} \times 560 \mathrm{~mm} \times$ $10 \mathrm{~mm}$ )) sheet was chosen as an artificial plant supporting layer for the aeroponic growth chamber. Further, the drill machine connected with the steel hole ( $25 \mathrm{~mm}$ diameter) maker was used to make the holes in the Styrofoam (A6 $(760 \mathrm{~mm} \times 560 \mathrm{~mm} \times$ $10 \mathrm{~mm}$ )) sheet. During making holes in the Styrofoam (A6) sheet, the drill machine must be held tightly in the selected place. After making the holes in the Styrofoam sheet, the second step was to place the plant holders in the Styrofoam sheet. Therefore, the plastic cups (A7 $(45 \mathrm{~mm} \times 30 \mathrm{~mm} \times 45 \mathrm{~mm}))$ and cotton round holes (A8 $(25 \mathrm{~mm} \times 25 \mathrm{~mm} \times 25 \mathrm{~mm})$ ) were selected as a plant holder material. Finally, the power supply line of the pressure pump, air compressor, and LED lights were attached in the extension to supply the power while the timer was used to control the spraying time and spraying interval of the atomization nozzle. Furthermore, the same material, methodology and strategy were used to develop the three aeroponic systems with the air-assisted atomizers. The mean difference between the three aeroponic systems was the type of the aeroponic atomization nozzle, whereas the air-assisted atomization nozzle with electrostatic spraying technology was additionally attached to the electrostatic generator (A12) and voltage distributor.

4.2.2 Aeroponic system developed with centrifugal atomization nozzle

The aeroponic system with centrifugal atomization nozzle was developed by using five atomization nozzles. Four nozzles were located in the middle and one nozzle was located at the center of the growth chamber (A4). In the developing process, firstly, the drill machine was used to make the holes in the growth chamber (A4) for fixing the atomization nozzles and the drain line. 
Besides, the copper internal thread straight connectors integrated with the centrifugal atomization nozzle (D) were tightly fixed in the growth chamber with a screw nut. Also, the pneumatic copper male thread joint connector was fixed into the nutrient drain line. Further, the pneumatic copper internal thread straight connectors were assembled with each copper internal thread straight connectors to receive the nutrient supply. However, to prevent the water leakages, all the threads were wrapped with a couple of layers of Teflon tape before assembly. After that, the flexible polyethylene water supply line (A21 $(6 \mathrm{~mm} \times 8 \mathrm{~mm}))$ was connected with each atomization nozzle through a pneumatic three-way connector (A23). Besides, the flexible polyethylene line $($ A21 $(6 \mathrm{~mm} \times 8 \mathrm{~mm}))$ was connected to the pneumatic copper male thread joint connector for recycling the nutrient solution. In the second step, the growth chamber (A4) assembled with the nutrient solution supply system and nutrient recycling line was placed above the aluminum frame (A1 $(745 \mathrm{~mm} \times 550 \mathrm{~mm} \times 800$ $\mathrm{mm})$ ). In addition, the water supply system consisted of the diaphragm pressure pump (A14), liquid pressure measuring pump (A18), and liquid flow meter (A17). Briefly, the diaphragm pressure pump (A14) water suction and water delivery portions were connected with a flexible polyethylene water line (A21 (12 $\mathrm{mm} \times 14 \mathrm{~mm})$ ), respectively. After that, the diaphragm pressure pump (A14) water delivery section line (A21 (12 mm $\times 14 \mathrm{~mm})$ ) was further combined with flexible polyethylene water line (A21 $(6 \mathrm{~mm} \times 8 \mathrm{~mm}))$ through the pneumatic reducer air pipe joint (A24 $(6 \mathrm{~mm} \times 12 \mathrm{~mm}))$. Then, the flexible polyethylene line (A21 (6 $\mathrm{mm} \times 8 \mathrm{~mm}$ )) coming from the pressure pump was connected with the fluid pressure measuring pump (A17), and liquid flow meter (A18) through the pneumatic copper male thread joint connector $(6 \mathrm{~mm} \times 10 \mathrm{~mm})$. Furthermore, the flexible polyethylene line $($ A21 $(6 \mathrm{~mm} \times 8 \mathrm{~mm})$ ) coming from the fluid pressure measuring pump (A17) was attached with the centrifugal atomizer through the pneumatic copper internal thread straight connector. The water suction line of the diaphragm pressure pump (A14) was further connected with the filter (A22) and then dipped in the nutrient reservoir (A9). In the last step, the flexible polyethylene line (A9 $(6 \mathrm{~mm} \times 8 \mathrm{~mm}))$ was connected with the aeroponic growth chamber (A4) through the pneumatic copper male thread joint connector and disposed of in the nutrient reservoir (A9) for nutrient recycling. Additionally, LED light (A10) stand and artificial plant supporting layer were developed by following the same methodology as reported for the aeroponic system developed with air-assisted atomizers.

4.2.3 Aeroponic system developed with ultrasonic fogger atomization nozzle

The aeroponic systems developed with $\mathrm{E}$ and $\mathrm{F}$ ultrasonic foggers were the same in the size and shape, but the difference was the nozzle type and number of the nozzle. While four E, six F, eight $\mathrm{G}$, and four $\mathrm{H}$ ultrasonic foggers were located in each aeroponic system. The aeroponic systems developed with $\mathrm{E}$ and $\mathrm{F}$ were mainly composed of a growth chamber, plant supporting tray, and aluminum frame. The aeroponic systems developed with $G$ and $\mathrm{H}$ were mainly composed of a growth chamber, plant supporting tray, aluminum frame, and nutrient reservoir. Furthermore, the aeroponic systems with ultrasonic fogger atomization nozzles were developed by following a similar methodology, as reported for air-assisted and centrifugal aeroponic atomization nozzles. However, the aeroponic systems developed with $\mathrm{E}$ and $\mathrm{F}$ ultrasonic foggers were easy to develop compared to the air-assisted, centrifugal atomizer, and other ultrasonic foggers.
In this system, the polystyrene foam (A5) was used to develop the aeroponic growth chamber. At the same, the growth chamber was used as a nutrient solution reservoir. Briefly, the drill machine was used to make the hole in the polystyrene foam (A5) for crossing the power lines of the ultrasonic foggers. After that, we placed the $\mathrm{E}$ and $\mathrm{F}$ ultrasonic foggers in aeroponic growth chambers, respectively, and placed the growth chambers on the aluminum frames (A1). Additionally, the plant supporting trays (A6 $(745 \mathrm{~mm} \times 445 \mathrm{~mm} \times 10 \mathrm{~mm})$ ) and LED frames were developed by following a similar procedure as reported for air-assisted atomization nozzle and centrifugal atomization nozzle. Finally, the axial fans (A11) were placed into the plant supporting trays (A6 $(745 \mathrm{~mm} \times 445 \mathrm{~mm} \times 10 \mathrm{~mm})$ ) for spreading the nutrient fog in the growth chambers (A5). The aeroponic system developed with medium-frequency ultrasonic nozzle (G) was mainly composed of a growth chamber, nutrient supply line, nutrient recycles line, nutrient reservoir, and an axial fan. Briefly, the growth chamber (A2) combined with a plant supporting tray (A3) and pneumatic copper male thread joint connector for nutrient recycling was manufactured from the local market. Firstly, the PVC pipe (A38 $(75 \mathrm{~mm})$ ) was connected with the growth chamber (A2) by using PVC tee $(75 \mathrm{~mm})$. Further, the PVC pipe $(75 \mathrm{~mm})$ was fixed in the wooden sheet. After that, the PVC pipe $(75 \mathrm{~mm})$ attached to the wooden sheet was located above the nutrient reservoir (A9). Besides, an axial fan (A11) with a PVC pipe $(75 \mathrm{~mm})$ was set on the wooden sheet. At the same time, the flexible polyethylene line $(8 \mathrm{~mm} \times 10 \mathrm{~mm})$ was fixed with the growth chamber by using the pneumatic copper male thread joint connector for recycling the used nutrient solution. In the second step, the medium-frequency ultrasonic nozzles $(\mathrm{G})$ were placed within the nutrient reservoir (A9). Moreover, the working principle of the aeroponic system developed with medium-frequency atomizer was: firstly, the foggers were subjected to work in the nutrient reservoir and create a fog. The axial fan was used for spreading the small nutrient fog into the air like a cloud and transfer the fog into the growth chamber through the PVC pipe. Finally, the aeroponic system developed with low-frequency ultrasonic atomization nozzle $(\mathrm{H})$ was mainly composed growth chamber, nutrient reservoir, plant supporting tray, and axial fan. Briefly, the system was developed by using four atomization nozzles $(\mathrm{H})$. The atomization nozzles were located in the middle of the growth chamber (A4). The distance between each nozzle was $240 \mathrm{~mm} \times 180 \mathrm{~mm}$ apart from each other. The total height of the proposed aeroponic system was $1000 \mathrm{~mm}$ above the ground level. Moreover, we followed a similar procedure discussed in the above sections to make the holes in the growth chamber (A4). Besides, the LED light frame, plant supporting tray, and axial fans were developed by the same procedure as reported for the other aeroponic systems. In the first step, we developed the growth chamber, plant supporting tray, and LED light stand and fixed the low-frequency ultrasonic nozzles $(\mathrm{H})$ in the growth chamber (A4) by using the sealed plastic glue gun. After that, we connected the water supply system line and water recycles line with the atomization nozzles and growth chamber, respectively. The water supply and water recycle lines were developed as reported for the centrifugal atomization nozzles. In addition, the low-frequency ultrasonic nozzle $(\mathrm{H})$ working principle was different as compared to the high-frequency ultrasonic and medium-frequency ultrasonic nozzles. The low-frequency ultrasonic nozzles were receiving the nutrient solution through the pressure pump (A14). 


\section{Evaluation of the proposed aeroponics system}

In order to evaluate the performance of the proposed aeroponics system, the systems were used to grow the lettuce and tomato plant in the greenhouse environment and under control conditions. It was observed that the plants successfully grew in the designed system. In addition, based on the obtained result, it could be concluded that the proposed design revealed a good sturdiness and relevance for plant cultivation in the future. The proposed design has a perspective for a sustainable future. The system is easy to design and has competed for structure. Thus, peoples could grow the plant in the system on their balconies, terrace, and rooms.

\section{Technical challenges}

The development of aeroponic system can be considered as a highly multidisciplinary approach drawing from environmental, mechanical, and civil engineering design concepts and plant-related biology, biochemistry, and biotechnology. Sometimes, specific measurements, schematic view, and control technologies also required abundant knowledge of subjects related to the field of computer science for automatic control systems. This high level of complexity necessarily demands in-depth knowledge and expertise of all involved fields. Furthermore, the electricity connection should be independent of the aeroponic system. Besides, in case of an emergency, additional power sources such as a stand-by generator or battery should always be ready with the system. For those places where power failures are frequent, that areas must need a good generator with an automatic startup system. Considering, the initial costs for components and installation, the aeroponic systems with air-assisted and centrifugal atomization nozzle are more expensive than ultrasonic fogger (high-frequency atomization nozzle). In addition, over time, if components are well maintained and used for many years, these higher initial costs can be recovered by reducing the labor costs, minimum inputs of fertilizers and pesticides with significantly higher plant yields.

\section{Routine and preventative maintenance of the aeroponic system}

In order to consider the aeroponic system, an efficient, trouble-free operation, low-cost, high production of plants for the long term, a routine, and regularly scheduled maintenance program must be carried out according to the requirements. Furthermore, it must be ensured that the aeroponic system is functional and protected from extreme weather conditions. Because of aeroponic cultivation is susceptible to the extreme or low climatic condition of the growth chamber. However, some of the key routine and preventative maintenance points are given below: 1) check that the power source is okay; 2) check that the nutrient reservoir tank is full; 3) change the nutrient solution on time; 4) check that the air pressure pumps are working properly; 5) check the leakages such as nutrient delivery and drain line; 6) check that atomization nozzles are working under satisfactory conditions such as clogging of the nozzles; 7) check that the chemical properties of the nutrient solution are in desired range; 8) check the environmental parameters are under the suitable range.

\section{Advantages of the proposed aeroponic systems}

The aeroponic systems proposed in this study are easy to redevelop. Even the local growers and untrained person can quickly redevelop the proposed aeroponic systems. The aeroponic systems were developed by purchasing the material from local markets. However, the system was developed in three main portions included a growth chamber, nutrient reservoir and the frame for growth chamber. The proposed systems had a compact structure, which makes the systems more efficient, easier to operate, and maintain. Moreover, it is suitable for big cities having less arable space and increasing rapid urbanization.

\section{Future prospectuses}

In a short time, aeroponic was adopted in many situations, from indoor laboratory experimental analysis to greenhouse cultivation. Several research studies developed aeroponic systems and used for the laboratory-scale plant cultivation. Few studies involved aeroponic systems that are representative of commercial or home operations. Until now, the system is not popular among the local growers, but the concept is dominated in the literature for laboratory-scale plant cultivation. The aeroponic has not yet been adopted on a broader scale and is still mostly unknown in several countries of the world because still many information about the system is hidden, such as the maintenance tasks and development of the aeroponic system. Therefore, the attempts would be made to provide brief information about the development, maintenance task, and benefits of the aeroponic system among farmers and the local community.

\section{Conclusions}

This study concluded that the adoption of modern farming techniques in traditional agriculture could be an alternative solution to deal with the increasing food security. The modern techniques involve much higher use of advanced technology and automation for land-use optimization. The aeroponic system is one of the revolutionary and more sustainable methods of the soilless system as it lowers the requirement of water and saves considerable space and soil. This study can provide important information about the aeroponic system to the researchers, farmers, and the local community interested in the aeroponic system but they think that aeroponic system design and maintenance is a very complicated task. They can develop the aeroponic system by purchasing the material from the local market anywhere in the world.

\section{Acknowledgements}

This work is financially supported by the National Natural Science Foundation of China Program (No. 51975255), Jiangsu Agriculture Science and Technology Innovation Funds (JASTIF) (CX (18)3048), Major Projects of Jiangsu University Natural Science Fund (No. 17KJA416001) and the "Project Funded by the Priority Academic Program Development of Jiangsu Higher Education Institutions (No. 37(2014)).

\section{[References]}

[1] Lakhiar I A, Gao J, Syed T N, Chandio F A, Buttar N A. Modern plant cultivation technologies in agriculture under controlled environment: A review on aeroponics. J. Plant Inter., 2018; 13: 338-358.

[2] Lakhiar I A, Jianmin G, Syed T N, Chandio F A, Buttar N A, Qureshi W A. Monitoring and control systems in agriculture using intelligent sensor techniques: A Review of the aeroponic system. J. of Sensors, 2018; Article ID 8672769. doi: 10.1155/2018/8672769.

[3] Iizumi T, Rahmankutty N. How do weather and climate influence cropping area and intensity? G. Food Sec., 2015; 4: 46-50.

[4] Fedoroff N. Food in a future of 10 billion. Agri \& Food Sec., 2015; 4: 
[5] Qiu R C, Wei S, Zhang M, Sun H, Li H, Liu G. Sensors for measuring plant phenotyping: A review. Int J Agric \& Biol Eng, 2018; 11(2): 1-17.

[6] Benke K, Tomkins B. Future food-production systems: vertical farming and controlled-environment agriculture. Sus: Sci, Pra and Pol., 2017; 13: 13-26.

[7] Li P F, Yang G, He X L, Li F D, Yan K, Wang Z L. Effects of drip irrigation on components of water cycle in arid inland areas: A case study of Manas river basin in northwestern China. Int J Agric \& Biol Eng, 2019; 12(1): 132-138.

[8] Lam H, Remais J, Fung M, Xu L, Sun S S. Food supply and food safety issues in China. The Lancet, 2013; 8(9882): 381.

[9] Xiao Y, Song Y, Wu X. How far has China's urbanization gone? Sustainability, 2018; 10(8): 2953.

[10] National Bureau of Statistics of China National Data, 1982-2016. Available online: http://data.stats.gov.cn/english/easyquery.htm?cn= C012017. Accessed on [2018-03-23].

[11] Bai X M, Shi P J, Liu Y S. Realizing China's urban dream. Nature, 2014; 509: 158-160

[12] United Nations, Department of Economic and Social Affairs, Population Division. World Population Prospects: The 2012 Revision, Highlights and Advance Tables. Working Paper No. ESA/P/WP.228. 2013. Available online: https://esa.un.org/unpd/wpp/publications/files/ wpp2012_highlights.pdf. Accessed on [2018-05-23].

[13] Qu D Y, Wang X B, Kang C P, Liu Y. Promoting agricultural and rural modernization through application of information and communication technologies in China. Int J Agric \& Biol Eng, 2018; 11(6): 1-4.

[14] Pimentel D, Berger B, Filiberto D. Water resources: agricultural and environmental issues. BioSci., 2004; 54(10): 909-918.

[15] Taher M, Kahil M T, Albiac J, Dinar A. Improving the performance of water policies: evidence from drought in Spain. Water, 2016; 8(2): 34

[16] Shamshiri R R, Kalantari F, Ting K C, Thorp K R, Hameed I A, Weltzien $\mathrm{C}$, et al. Advances in greenhouse automation and controlled environment agriculture: A transition to plant factories and urban agriculture. Int $\mathrm{J}$ Agric \& Biol Eng, 2018; 11(1): 1-22.

[17] Shamshiri R R, Weltzien C, Hameed I A, Yule I J, Grift T E, Balasundram $\mathrm{S} \mathrm{K}$, et al. Research and development in agricultural robotics: A perspective of digital farming. Int J Agric \& Biol Eng, 2018; 11(4): $1-14$.

[18] Shamshiri R R, Hameed I A, Pitonakova L, Weltzien C, Balasundram S K, Yule I J, et al. Simulation software and virtual environments for acceleration of agricultural robotics: Features highlights and performance comparison. Int J Agric \& Biol Eng., 2018; 11(4): 15-31.

[19] Badgery-Parker J. The greenhouse. Agnote DPI/249. New South Wales. 1999.

[20] Shamshiri R R, Jones J W, Thorp K R, Ahmad D, Man H C, Taheri S. Review of optimum temperature, humidity, and vapour pressure deficit for microclimate evaluation and control in greenhouse cultivation of tomato: a review. Int. Agrophys., 2018; 32: 287-302.

[21] Shamshir R, Ismail W I W. A Review of greenhouse climate control and automation systems in tropical regions. J. Agric. Sci. Appl., 2013; 2(3): 176-183.

[22] FAO. World Agriculture: Toward 2015/2030. Summary report. Food and Agriculture Organization of the United Nations. Rome, 2002

[23] Chang T, Zhang Y, Zhang Z, Shao X, Wang W, Zhang J, et al. Effects of irrigation regimes on soil $\mathrm{NO}^{3-}-\mathrm{N}$, electrical conductivity and crop yield in plastic greenhouse. Int J Agric \& Biol Eng, 2019; 12(1): 109-115.

[24] Pardossi A, Tognoni F, Incrocci L. Mediterranean greenhouse technology. Chronica Horticulturae, 2004; 44(2): 28-34.

[25] Diego A, Moreno D A, Gemma V, Joaquín H, Nicolás C, Luis R. Accumulation of $\mathrm{Zn}, \mathrm{Cd}, \mathrm{Cu}$, and $\mathrm{Pb}$ in Chinese cabbage as influenced by climatic conditions under protected cultivation. J Agric Food Chem., 2002; 50(7): 1964-1969.

[26] Pulgar G, Moreno D A, Víllora G, Hernandez J, Castilla N, Romero L. Production and composition of Chinese cabbage under plastic row covers in southern. Spain J Hortic Sci Biotech., 2001; 76(5): 608-611.

[27] Song J X, Meng Q W, Du W F, He D X. Effects of light quality on growth and development of cucumber seedlings in controlled environment. Int J Agric \& Biol Eng, 2017; 10(3): 312-318.

[28] Shamshiri R R, Mahadi M R, Thorp K R, Ismail W I W, Ahmad D, Man H C. Adaptive management framework for evaluating and adjusting microclimate parameters in tropical greenhouse crop production systems. Plant Engin., 2017; pp.167-191. doi: 10.5772/intechopen.69972

[29] Bailey B J. Control and monitoring of glasshouses. Proceedings of the
UK Controlled Environment Users' Group, 2002; 13: 2-5.

[30] Bot G P A. Greenhouse climate: From physical processes to a dynamic model. Ph.D. Thesis. Agricultural University. Wageningen, 1983.

[31] Zhang Y, Mahrer Y, Margolin M. Predicting the microclimate inside a greenhouse: an application of a one-dimensional numerical model in an unheated greenhouse. Agri. and Forest Meteo., 1997; 86: 291-297.

[32] Bakker J C. Model application for energy efficient greenhouses in The Netherlands: Greenhouse design, operational control and decision support systems. Acta Hortic., 2006; 718: 191-202.

[33] Shamshiri R. Measuring optimality degrees of microclimate parameters in protected cultivation of tomato under tropical climate condition Measurement, 2017; 106: 236-244.

[34] Heravi A, Ahmad D, Hameed I A, Shamshiri R R, Balasundram S K Yamin M. Development of a field robot platform for mechanical weed control in greenhouse cultivation of cucumber. In Zhou J, Zhang B H Eds, Agri. Rob-Fund and Appli., IntechOpen, 2018; pp.1-29.

[35] Sultan M. Miyazaki T, Saha B B, Koyama S. Steady-state investigation of water vapor adsorption for thermally driven adsorption-based greenhouse air-conditioning system. Rene. Ener., 2016; 86: 785-795.

[36] Sultan M. Miyazaki T, Saha B B, Koyama S, Maisotsenko V S Steady-state Analysis on Thermally Driven Adsorption Air-conditioning System for Agricultural Greenhouses. Proc. Engi., 2015; 118: 185-192.

[37] Sultan M. Miyazaki T. Energy-efficient air-conditioning systems for nonhuman applications. In: Refrigeration; InTechOpen Publisher; ISBN\# 978-953-51-3498-5; ISBN(Print)\# 978-953-51-3497-8.

[38] Johnson W C, Jackson L E, Ochoa O, van Wijk R, Peleman J, Clair D A S, Michelmore R W. Lettuce, a shallow-rooted crop, and Lactuca serriola, its wild progenitor, differ at QTL determining root architecture and deep soil water exploitation. Theor. Appl. Genet., 2000; 101: 1066-1073.

[39] Bozkurt S, Mansuroglu G S. The effects of drip line depths and irrigation levels on yield, quality and water use characteristics of lettuce under greenhouse. Afr. J. Biotechnol., 2011; 10: 3370-3379.

[40] Gözener B, Dereli H. Greenhouse tomato producers' views on soilless agriculture in Antalya. Turk. J. of Agri. - Food Sci. and Techno., 2018; 6(4): 460-463.

[41] Otazú V. Manual on quality seed potato production using aeroponics. 2014. International Potato Center (CIP), Lima, Peru. http://cippotato.org.research/publication/manaul-on-quality-seed-potato-pr oduction-using-aeroponics. Accessed on [2018-05-23].

[42] Calor A H, Factor T L, Feltran J C, Watanabe E Y, de Moraes C C, Purquerio L F V. Electrical conductivity of the nutrient solution and plant density in aeroponic production of seed potato under tropical conditions (winter/spring). Bragantia, Campinas., 2017; 76: 23-32.

[43] Savvas D, Gianquinto G, Tuzel Y, Gruda N. Soilless culture. Good agricultural practices for greenhouse vegetable crops, principles for mediterranean climate areas. FAO Plant Pro and Prot Paper., 2013; 217: 303-354.

[44] Grafiadellis I, Mattas K, Maloupa E, Tzouramani I, Galanopoulos K. An economic analysis of soilless culture in Gerbera production. HortSci., 2000; 35(2): 300-303.

[45] Raviv M, Lieth J H. Significance of soilless cultivation in agriculture. In: Raviv M, Lieth J H. (Eds.), Soilless culture: Theory and practice. academic press, San Diego, USA, 2008; pp.1-11.

[46] Nejad A R, Ismaili A. Changes in growth, essential oil yield and composition of geranium (Pelargonium graveolens L.) as affected by growing media. J. Sci. Food Agric., 2014; 94(5): 905-910.

[47] Butler J D, Oebker N F. Hydroponics as a Hobby- Growing Plants without Soill. Circular 844. Information Office, College of Agriculture, University of Illinois, Urbana, IL 61801, 2006.

[48] Pual C. Heath and hydroponic. Practical Hydroponic and Greenhouse., 2000; 53: 28-30.

[49] Barrett G E, Alexander P D, Robinson J S, Bragg N C. Achieving environmentally sustainable growing media for soilless plant cultivation systems - A review. Sci. Horti., 2016; 212: 220-234.

[50] Dorais M, Menard C, Begin E. Risk of phytotoxicity of sawdust substrate for greenhouse vegetables. Acta Horti., 2007; 761: 589-594.

[51] Ehret D L, Helmer T. A new wood fibre substrate for hydroponic tomato and pepper crops. Can J. of Plant Sci., 2009; 89(6): 1127-1132.

[52] Mahamud S, Manisah M D. Preliminary studies on sago waste as growing medium for tomato. Acta Horti., 2007; 742: 163-168.

[53] Nurznski J. The yield of greenhouse tomato grown in straw and rockwool. Folia Horti., 2006; 18(2): 17-23.

[54] Donnan R. Hydroponics around the world. In: Practical Hydroponics 
\& Greenhouses. July/August, 1998.

[55] Seymour G. Review of commercial hydroponic crop production system. In: Commercial Hydroponics in Australia: A Guide for Growers, Pro-Set Pty Ltd, Hobart; 1993.

[56] Raviv M. The future of composts as ingredients of growing media. Acta Horti., 2011; 891: 19-32.

[57] Raviv M. Suppressing soil-borne disease of container-grown plants using composts. Acta Horti., 2011; 893: 169-181.

[58] Bilderback T E, Warren S L, Owen J S, Albano, J P. Healthy substrates need physicals too! Hort techn., 2005; 15(4): 747-751.

[59] Asaduzzaman M d, Saifullah M d, Mollick A S R, Hossain M d, Halim G M A, Asao T. Influence of Soilless Culture Substrate on Improvement of Yield and Produce Quality of Horticultural Crops. 2015. https://www.intechopen.com/books/soilless-culture-use-of-substrates-for-t he-production-of-quality-horticultural-crops. Accessed on [2018-05-23].

[60] Palande V, Zaheer A, George K. Fully automated hydroponic system for indoor plant growth. Pro. Comp. Sci., 2018; 129: 482-488.

[61] Kheir Al-Kodmany. The vertical farm: A review of developments and implications for the vertical city. Build, 2018; 8: 24.

[62] Harris D. Hydroponics: A Practical Guide for the Soilless Grower, 2nd ed.; NewHolland Publishing: London, UK, 1992.

[63] Munoz H, Joseph J. Hydroponics: Home-based vegetable production system, inter-american institute for cooperation on agriculture (IICA). June 2010. http://legacy.iica.int/Eng/regiones/caribe/guyana/ IICA\%20Office\%20Documents/Hydroponics\%20Manual/Hydroponics $\% 2$ 0Manual.pdf. Accessed on [2018-05-23].

[64] Hedenblad E, Olsson M. Urban growth analysis of crop consumption and development of a conceptual design to increase consumer adoption of vertical greenhouses. Master's Thesis, Chalmers University of Technology, Gothenburg, Sweden, 2017. http://www.tekniskdesign.se/ download/ Hedenblad_Olsson.pdf. Accessed on [2018-05-23].

[65] Pullano G. Indoor vertical grower touts concept's benefits. VGN vegetable grower news, 15 August 2013. http://vegetablegrowersnews.com/ index. php/magazine/article/indoor-vertical-growertouts-concepts-benefits. Accessed on [2018-05-23]

[66] Green Spirit Farms. Sustainable Vertical Farming. Available online: http://www.greenspiritfarms.com/inthe-news. Accessed on [2017-07-15].

[67] Riggio G M, Jones S L, Gibson K E. Risk of human pathogen internalization in leafy vegetables during lab-scale hydroponic cultivation. Horticulture, 2019; 5: 25 .

[68] Resh H M. Hydroponic food production: a definitive guidebook for the advanced home gardener and the commercial hydroponic grower, 7th ed.; CRC Press Taylor and Francis Group: Boca Raton, FL, USA, 2012; ISBN 9781439878675

[69] Food and Agriculture Organization (FAO) of the United Nations. Good agricultural practices for greenhouse vegetable crops: principles for mediterranean climate areas; FAO: Rome, Italy, 2013.

[70] Palm H W, Knaus U, Appelbaum S, Goddek S, Strauch S M, Vermeulen $\mathrm{T}$, et al. Towards commercial aquaponics: A review of systems, designs, scales and nomenclature. Aquac. Int., 2018; 39: 510.

[71] Delaide B, Goddek S, Gott J, Soyeurt H, Haissam J M, Lalman J, et al. Lettuce (Lactuca sativa L. var. Sucrine) growth performance in complemented aquaponic solution outperforms hydroponics. Water, 2016; 8: 467

[72] Rakocy J E. Aquaponics-integrating fish and plant culture. In Aquaculture Production Systems, Tidwell J H, Ed., John Wiley and Sons: Hoboken, NJ, USA, 2012; pp.343-386.

[73] Rakocy J E, Masser M P, Losordo T M. Recirculating aquaculture tank production systems: Aquaponics integrating fish and plant culture. SRAC Publ. South Reg. Aquac. Cent., 2006; 16: 454.

[74] Delaide B, Delhaye G, Dermience M, Gott J, Soyeurt H, Jijakli M H. Plant and fish production performance, nutrient mass balances, energy and water use of the PAFF Box, a small-scale aquaponic system. Aquac. Eng., 2017; 78: 130-139.

[75] Buzby K M, Lin LS. Scaling aquaponic systems: Balancing plant uptake with fish output. Aquac. Eng., 2014; 63: 39-44.

[76] Turcios A E, Papenbrock J. Sustainable treatment of aquaculture effluents-what can we learn from the past for the future?. Sus., 2014; 6 : 836-856.

[77] Schmautz Z, Loeu F, Liebisch F, Graber A, Mathis A, Bulc T G, et al. Tomato productivity and quality in aquaponics: Comparison of three hydroponic methods. Water, 2016; 8: 533.
[78] Schröter I. Mergenthaler M. Neuroeconomics meets aquaponics: An eye-tracking pilot study on perception of information about aquaponics. Sus., 2019; 11: 3580.

[79] Despommier D. The vertical farm: Feeding the world in the 21st century; Thomas Dunne Books: New York, NY, USA, 2010.

[80] Healy R G, Rosenberg J S. Land use and the states; Routledge: New York, NY, USA, 2013.

[81] Evolving science. Vertical farms in cities are the future of urban farming. Environment. June 20, 2017. https://www.evolving-science.com/ environment/vertical-farms-cities-are-future-urban-farming-00288. Accessed on [2018-05-23].

[82] Clawson J M, Hoehn A, Stodieck L S, Todd P. NASA review of aeroponics, Aeroponics for spaceflight plant growth, society of automotive engineers, Inc, 2000, http://aeroponicsdiy.com/ nasa-review-of-aeroponics/. Accessed on [2018-05-23].

[83] Nichols M A, Christie C B. Continuous production of greenhouse crops using aeroponics. Proc. IS on Trop. Subtrop. Greenhouses. Eds. S Chen and T.T. Lin. Acta Hort., 2002; 578: 289-291.

[84] Martin-Laurent F, Lee S K, Tham F Y, He J, Diem H G, Durand P. A new approach to enhance growth and nodulation of Acacia mangium through aeroponic culture. Biol Fertile Soil, 1997; 25: 7-12.

[85] Martin-Laurent F, Tham F Y, Lee S K, He J, Diem H G. Field assessment of aeroponically grown and nodulated acacia mangium. Aust J Bot., 2000; 48: 109-114.

[86] Nir I. Growing plants in Aeroponics growth system. Acta Hort., 1982; 126: 435-445.

[87] Ritter E, Angulo B, Riga P, Herran J, Relloso J, San Jose M. Comparison of hydroponic and aeroponic cultivation systems for the production of potato minitubers. Potato Res., 2001; 44: 127-135.

[88] Farran I, Mingolo-Castel A M. Potato minituber production using aeroponics: Effect of plant density and harvesting intervals. Amer J of Potato Res, 2006; 83: 47-53.

[89] NASA Spinoff. Progressive plant growing has business blooming. In: Environmental and Agricultural Resources. New York: NASA Spinoff, 2006; pp.64-77.

[90] Stoner R J, Clawson J M. A high performance, gravity insensitive, enclosed aeroponic system for food production in space. Principal Investigator, NASA SBIR NAS10-98030, 1998.

[91] Peterson L A, Krueger A R. An intermittent aeroponics system. Crop Sci., 1998; 28: 712-713.

[92] Buer C S, Correll M J, Smith T C, Towler M J, Weathers P J, Nadler M, et al. Development of a nontoxic acoustic window nutrient-mist bioreactor and relevant growth data. in vitro cell. Dev Biol-Plant, 1996; 32 299-304.

[93] Clayton M F, Lamberton J A. A study of root exudates by the fog-box technique. Aust J Biol Sci, 1964; 17: 855-866.

[94] Park H S, Chiang M H. Effects of form and concentration of nitrogen in aeroponic solution on growth, chlorophyll, nitrogen contents and enzyme activities in Cucumissativus L. Plant $\mathrm{J}$ of the Kore Soci for Horti Sci., 1997; 38: 642-646.

[95] Burgess T, McComb J, Hardy G, Colquhoum I. Influence of low oxygen levels in aeroponics chambers on eucalypt roots infected with phytophthora cinnamomi. $\quad$ Plant Dis., 1998; 82: 368-373.

[96] Garrido I, Espinosa F, Paredes M A, Alvarez-Tinaut M C. Effect of some electron donors and acceptors on redox capacity and simultaneous net $\mathrm{H}^{+} / \mathrm{K}+$ fluxes by aeroponic sunflower seedling roots: evidence for a $\mathrm{CN}^{-}$-resistant redox chain accessible to nonpermeative redox compounds. Protoplasma, 1998; 205: 141-155.

[97] Garrido I, Espinosa F, Paredes M A, Alvarez-Tinaut M C. Net simultaneous hydrogen and potassium ion flux kinetics in sterile aeroponics sunflower seedlings roots: effects of potassium ion supply, valinomycin, and dicyclohexylcarbodiimide. J. plant Nutr., 1998; 21(1): 115-137.

[98] Mirza M, Younus M, Hoyano Y, Currie R. Greenhouse production of Echinacea and other medicinal plants. Paper presented at Opportunities and Profits II: Special Crops into the 21st Century, Edmonton, AB, Canada, 1998

[99] Mohammad A, Khan A G, Kuek C. Improved aeroponic culture of inocula of arbuscularmycorrhizal fungi. Mycorrhiza, 2000; 9: 337-339.

[100] Stoner R J. Aeroponics versus bed and hydroponic propagation. Florists Review, 1983; 173: 4477.

[101] Button T, Wood M E. The O'Hare urban garden: A sustainable airport food \& beverage supply chain initiative. environmental management of 
international tourism development, E-118 Harvard University Extension School, 2011.

[102] Anitha P, Periasamy P S. Energy efficient greenhouse monitoring in the aeroponics system using Zigbee networks. Asian J. of Res. in Soc. Sci. and Hum., 2016; 6(6): 2243-2250.

[103] Guizhen H. Multi-physical field simulation and structure optimization design of ultrasonic atomization cultivator. Master's Thesis, Institute of Agricultural Equipment Engineering, Jiangsu University, 2013. (in Chinese).

[104] Gao J, Guizhen H, Wenhu Y. Variation of root-zone droplet deposition, temperature and humidity of truss ultrasonic atomization cultivator. Transaction of the CSAE, 2013; 29(6): 185-192. (in Chinese).

[105] NASA. Progressive Plant Growing Has Business Blooming. 2006.

[106] Juncal S, Ferguson A, Berruti M. Commercial Aeroponics System. 2016. Patent No.: US 9,345,207 B2

[107] David R. Aeroponic growing apparatus and method. 2011. (US Patent Publication No 2011/0023359 A1).

[108] Rajan R, Pandit A B. Correlations to predict droplet size in ultrasonic atomization. Ultrasonics, 2001; 39(4): 235-255.

[109] Avvaru B, Patil M N, Gogate P R, Pandit A B. Ultrasonic atomization: effect of liquid phase properties. Ultrasonics, 2006; 44(2): 146-158.

[110] Zhai C Y, Zhao C J, Wang X, Li W, Li W, Zhu R X. Nozzle test system for droplet deposition characteristics of orchard air-assisted sprayer and its application. Int J Agric \& Biol Eng, 2014; 7(2): 122-129.

[111] Gao J, Zhang J, Lu D. Design and atomization experiments of an ultrasonic atomizer with a levitation mechanism. Appl. Eng. in Agric., 2016; 32(4): 353-360.
[112] Buckseth T, Sharma A K, Pande K K, Singh B P, Muthuraj R. Methods of pre-basic seed potato production with special reference to aeroponic- a review. Sci Horti., 2016; 204: 79-87.

[113] Lakhiar I A, Liu X D, Wang G Q, Gao J M. Experimental study of ultrasonic atomizer effects on values of $\mathrm{EC}$ and $\mathrm{pH}$ of nutrient solution. Int J Agric \& Biol Eng, 2018; 11(5): 59-64.

[114] Chiipanthenga M, Maliro M, Demo P, Njoloma J. Potential of aeroponics system in the production of quality potato (Solanum tuberosum L.) seed in developing countries. African J. of Biotechn., 2012; 11(17): 3993-3999

[115] Christie C B, Nichols M A. Aeroponics - A production system and research tool. South Pacific Soilless Culture Conference. Acta Hort., 2004; 648: 185-190.

[116] Lakhiar I A, Gao J, Xu X, Syed T N, Chandio F A, Jing Z, et al. Effects of various aeroponic atomizers (droplet sizes) on growth, polyphenol content, and antioxidant activity of leaf lettuce (Lactuca sativa L). Transactions of the ASABE, 2019; 62(6): 1475-1487.

[117] Appah S, Wang P, Ou M X, Gong C, Jia W D. Review of electrostatic system parameters, charged droplets characteristics, and substrate impact behavior from pesticides spraying. Int J Agric \& Biol Eng, 2019; 12(2): 1-9.

[118] Law S E. Agricultural electrostatic spray application: a review of significant research and development during the 20th century. J. of Electr., 2001; 52: 25-42.

[119] Law S E. Embedded-Electrode electrostatic-induction spray charging nozzle: Theoretical and engineering design. ASABE, 1978; 21: 1096-1104. 